\title{
Development of a real-time RT-PCR and Reverse Line probe Hybridisation assay for the routine detection and genotyping of Noroviruses in Ireland
}

\author{
John F Menton*, Karen Kearney and John G Morgan
}

\author{
Address: Lab 439, Food Science Building, Department of Microbiology, University College Cork, Cork, Republic of Ireland \\ Email: John F Menton* - j.menton@ucc.ie; Karen Kearney - kearney_karen@hotmail.com; John G Morgan - j.morgan@ucc.ie \\ * Corresponding author
}

Published: 6 September 2007

Virology Journal 2007, 4:86 doi:10.1186/1743-422X-4-86

This article is available from: http://www.virologyj.com/content/4/l/86

(C) 2007 Menton et al; licensee BioMed Central Ltd.

This is an Open Access article distributed under the terms of the Creative Commons Attribution License (http://creativecommons.org/licenses/by/2.0), which permits unrestricted use, distribution, and reproduction in any medium, provided the original work is properly cited.
Received: 13 July 2007

Accepted: 6 September 2007

\begin{abstract}
Background: Noroviruses are the most common cause of non-bacterial gastroenteritis. Improved detection methods have seen a large increase in the number of human NoV genotypes in the last ten years. The objective of this study was to develop a fast method to detect, quantify and genotype positive NoV samples from Irish hospitals.

Results: A real-time RT-PCR assay and a Reverse Line Blot Hybridisation assay were developed based on the ORFI-ORF2 region. The sensitivity and reactivity of the two assays used was validated using a reference stool panel containing $14 \mathrm{NoV}$ genotypes. The assays were then used to investigate two outbreaks of gastroenteritis in two Irish hospitals. 56 samples were screened for NoV using a real-time RT-PCR assay and 26 samples were found to be positive. Genotyping of these positive samples found that all positives belonged to the GII/4 variant of NoV.

Conclusion: The combination of the Real-time assay and the reverse line blot hybridisation assay provided a fast and accurate method to investigate a NoV associated outbreak. It was concluded that the predominant genotype circulating in these Irish hospitals was GII/4 which has been associated with the majority of NoV outbreaks worldwide. The assays developed in this study are useful tools for investigating NoV infection.
\end{abstract}

\section{Background}

Noroviruses (NoV) are one of the most common causes of acute non-bacterial gastroenteritis in humans. Formerly known as "Norwalk virus", NoV was first recognised in October 1968 in an elementary school in Norwalk, Ohio [1]. It is highly contagious and can be transmitted as an aerosol, through direct contact or via the faecal oral route causing explosive outbreaks in environments where people are in close contact such as hospitals, retirement homes, cruise ships, army bases, hotels and holiday resorts [2-5]. Symptoms consist of severe vomiting and diarrhoea which can last for $24-72$ hours. NoV is a nonenveloped virus with a capsid of 27-35 $\mathrm{nm}$ in diameter and is a member of the Calicivirus family. The virion consists of a single positive strand RNA genome of approximately $7.6 \mathrm{~kb}$ and encodes three open reading frames. ORF1 encodes the nonstructural proteins, ORF2 encodes the major capsid protein VP1 and ORF3 encodes a minor structural protein VP2.

The emergence of $\mathrm{NoV}$ as the most prominent cause of gastroenteritis over the last ten years is due to improved 
methods of detection, which have allowed accurate identification of the viruses responsible for these outbreaks. The most utilised methods are Electron Microscopy (E.M) and Reverse Transcription Polymerase Chain Reaction (RT-PCR). RT-PCR is the preferred method as it is rapid and very sensitive; however, it relies heavily on precise primer design which can be problematic due to the high level of genetic variability between NoV strains. Human NoV can be divided into three Genogroups GI, GII and GIV which can be further subdivided into 8, 17 and 1 genotypes respectively based on VP1 sequences [6].

The use of a broadly reactive primer pairs allows accurate detection of NoV, however typing the strain of $\mathrm{NoV}$ responsible for an outbreak still relies heavily on sequencing, which can be time consuming

In this study, we describe a real-time RT-PCR assay based on SYBR Green chemistry utilising a broadly reactive pair of primers for both GI and GII NoV based on the highly conserved ORF1-ORF2 junction. A reverse line blot hybridisation assay was developed within this ORF1ORF2 junction by designing 25 genotype specific probes to allow rapid detection and typing of an outbreak. This method was used to detect and genotype virus present in the stools of patients suffering from gastroenteritis in two outbreaks which occurred in Irish Hospitals in 2005 and 2006.

\section{Results}

Development and validation of a SYBR green based RealTime RT-PCR assay for NoV

Two degenerate reverse primers G1NVR and G2NVR (Table 1) were designed based on multiple alignments of 30 Genogroup I sequences and 120 Genogroup II sequences. The sequences were $400 \mathrm{bp}$ segments of the ORF1-ORF2 junction (region 5288-5665 nts Southampton and region 5005-5387 nts Lordsdale). These primers were combined with previously published primers designed by Kageyama et al., 2003 [7] to detect human NoV.

Two separate Real-time RT-PCR assays were designed based on SYBR green chemistry for GI and GII NoV. This assay utilised a fluorescence acquisition step at $85^{\circ} \mathrm{C}$ for GI and $84^{\circ} \mathrm{C}$ for GII to melt primer dimers thus ensuring only amplified product was detected. Standard curves were created in triplicate using serial dilutions of plasmids containing GI/2 and GII/4 PCR products corresponding to Southampton virus and Oxford B2S16. Detection levels of these plasmid molecules were $10^{7}$ to $10^{1}$ for GI and $5 \times$ $10^{7}$ to $5 \times 10^{1}$ for GII (Fig. 1A and Fig. 2A). Melting curve analysis identified positive samples by large peaks at $\sim 90^{\circ} \mathrm{C}$ and $\sim 88^{\circ} \mathrm{C}$ respectively for GI and GII NoV (Fig. $1 \mathrm{C}$ and Fig. 2C). A stool panel containing 5 genotypes of
GI NoV and 9 genotypes of GII NoV was obtained from external laboratories (Table 2). This stool panel was applied to the Lightcycler assay and all the genotypes were detectable.

\section{Detection and quantification of human NoV by Real-Time RT-PCR}

56 samples were taken from two outbreaks of NoV in two Irish hospitals in 2005 and 2006. These samples were applied to the GII NoV real-time assay and 26 samples were detected as positive for GII NoV. Samples negative for GII NoV were applied to the GI assay and were also found to be negative for GI NoV. Samples were quantified using the plasmid standard curve. The lowest $\mathrm{Ct}$ value was at point 35.79 , giving a concentration of $2.67 \times 10^{2}$ molecules of NoV cDNA or $2.67 \times 10^{6}$ per gram of stool. The highest $\mathrm{Ct}$ value was at point 21.93 giving a concentration of $7.53 \times 10^{5}$ molecules of NoV cDNA or $7.53 \times 10^{9} \mathrm{~mol}-$ ecules per gram of stool. The average number of NoV molecules per gram of stool was $1.02 \times 10^{9}$ molecules.

\section{Design of oligonucleotide probes for development of reverse line probe hybridization assay}

Twenty-five oligonucleotide probes were designed within the region of the COG1F-G1NVR and COG2F-G2NVR PCR products. Design was based on a annealing temperature of at least $60^{\circ} \mathrm{C}$ and a minimum of 3 mismatches between the probe and the other genotypes. All the probes were submitted to BLASTn program National Centre for Biotechnology Information to verify specificity. A probe was designed for each genotype within GI (1-8) and GII (1-17) NoV classified according to Zheng et al., 2006 [6]. The GII/11 probe was excluded from the membrane as this genotype has only been associated with porcine $\mathrm{NoV}$.

Probes were covalently bound to a negatively charged nylon membrane and the membrane was rotated $90^{\circ}$ horizontally. Denatured PCR products of all 14 positive samples in the NoV panel were annealed to the membrane giving specific binding i.e. single dots were observed for all respective probes with the exception of probe GII/2 which binds both GII/2 and GII/6 (Fig. 3).

\section{Genotyping of NoV positive samples}

26 positive samples from the two outbreaks were applied to the membrane along with 9 GII samples from the stool panel. The 12 RT-PCR positive samples from the 2006 outbreak and the 14 positive samples from the 2005 outbreak all bound the GII/4 probe (Fig. $4 \mathrm{~A}$ and $4 \mathrm{~B}$ ).

\section{Discussion}

The reverse primers designed in this study were combined with the forward primers designed by Kageyama et al., 2003 [7] to create a conventional RT-PCR assay for human NoV. These primer pairs compared favourably (data not 
Table I: Primers and probes used for Lightcycler RT-PCR and Reverse Line Blot hybridization assay.

\begin{tabular}{lll}
\hline Primers & Primer Sequence & Reference \\
\hline COGIF & CGY TGG ATG CGN TTY CAT GA & {$[7]$} \\
GINVR & ACC CAR CCA TTA TAC ATY TG & \\
COG2F & CAR GAR BCN ATG TTY AGR TGG ATG & [7] \\
& AG & \\
G2NVR & ACC NGC ATA NCC RTT RTA CAT TC \\
& \\
Probes & \\
& \\
GI/1 & TCT TGC AAT GGA TCC TGT RGC RG \\
GI/2 & GAA CCC GTG GCY GGG CCA AC \\
GI/3 & CCA GAG GCA AAY ACA GCT GAG \\
GI/4 & TGA CCC TGT GGC TGG CTC CTC \\
GI/5 & ATG CTG AAC CAC TGC CWC TTG AT \\
GI/6 & CAA ATT TCA ATG GAY CCT GTT GCG \\
GI/7 & GGT AGT GGG CGC CGC AAC C \\
GI/8 & TGC GGT TGC TAC TGC CGG CCA \\
& \\
GII/I & CGA GAC GAT GGC MCT CGA ACC G \\
GII/2 & TAT AGA CCC TTG GAT TAG AGC A \\
GII/3 & CAA TGG CGC TAG ABC CAG TGG CG \\
GII/4 & GAC GCC AAC CCA TCT GAT GGG TC \\
GII/5 & GGT GGG GGC GTC TTT AGC C \\
GII/6 & CTC AAT CGC AGC TCC TGT YGT \\
GII/7 & GCA TCG CTG GCG ACA CCA GTT G \\
GII/8 & TCA ACC ATG AGG TCA TGG CCA TA \\
GII/9 & CCC CGG GTG AGT TCT TGC TYG A \\
GII/10 & TTC CCC TGG AGA AGT ACT CCT \\
GII/I2 & CGA ACT AAA TCC ATA CCT AGC ACAC \\
GII/I3 & CAG TGG CGG GAC AAA CCA AC & \\
GII/14 & CTC TCC TGG AGA ACT CCT ACT TGA T \\
GII/15 & GAA GTC TTG CCT TTA GAG CCC GTC & \\
GII/16 & CAG TTG CGG GAG CTT CAA TCG CT \\
GII/17 & CCT CCC TTT GGA ACC AGT TGC \\
\hline & \\
\hline
\end{tabular}

shown) with three previously published RT-PCR assays [7-9]. A Real-Time SYBR green RT-PCR assay was then developed based on the primer pairs to detect and quantify both GI and GII NoV in the Irish population. The chemistry of SYBR green allows non-specific products such as primer dimers to yield a fluorescent signal. This was overcome by incorporating a fluorescent read step at $85^{\circ} \mathrm{C}$ for the GI assay and $84^{\circ} \mathrm{C}$ for the GII assay. This adjustment means that only NoV RT-PCR product is measured by the Real-Time thermocycler.

The assay demonstrated good sensitivity, detecting from $10^{7}$ to $10^{1}$ molecules of plasmid DNA for GI NoV and $5 \times$ $10^{7}$ to $5 \times 10^{1}$ for GII NoV. The $\mathrm{R}_{2}$ values for both standard curves were 1.00 with a slope of -3.5 and -3.7 respectively for GI and GII NoV (Fig. 1B and Fig. 2B). Melting curve analysis showed a positive peak at $\sim 90^{\circ} \mathrm{C}$ and $88^{\circ} \mathrm{C}$ for GI and GII NoV. The broad reactivity of the assay was validated using a panel of stool samples collected containing

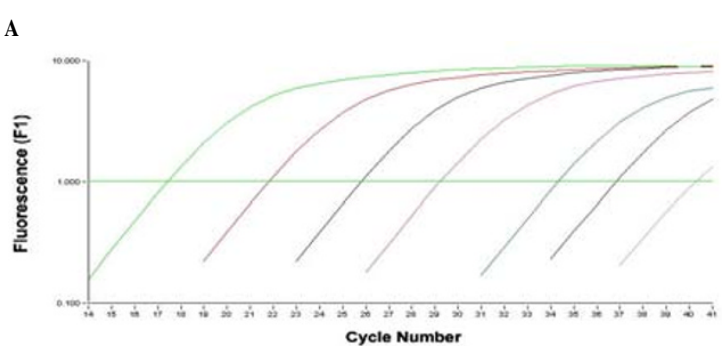

B

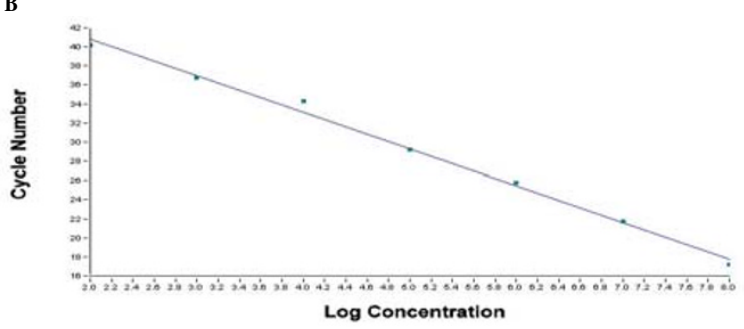

C

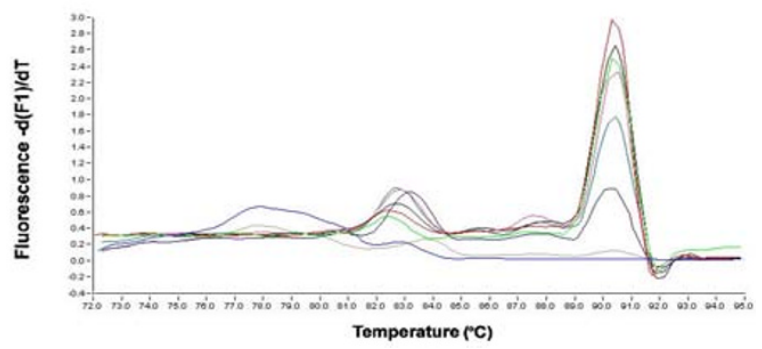

Figure I

(A) Amplification of standards showing fluorescence versus cycle number concentration of $10^{7}-10^{1}$ molecules are shown from left to right. (B) Standard curve of $\mathrm{Gl}$ assay $\mathrm{R}_{2}$ $\mathrm{I} .00$ and a slope of -3.8 was obtained. (C) Melting curve of $\mathrm{Gl}$ standards showing melting point at $90^{\circ} \mathrm{C}$ in descending order $10^{7}-10^{1}$ molecules.

5 GI and 9 GII NoV genotypes. The GI based NoV assay detected all five of the different genotypes of GI stool panel (GI/1, GI/2, GI/3, GI/4 and GI/6) and showed no cross reactivity with any of the GII NoV. The GII assay detected all 9 Genotypes of the Genogroup II stool panel (GII/2, GII/3, GII/4, GII/6, GII/8, GII/10, GII/12, GII/16, GII/17) and showed no cross reactivity with GI NoV.

It was not possible to obtain all of the NoV genotypes to validate the assay described. GI/5, GI/7 and GI/8 were not available for Genogroup I and GII/1, GII/5, GII/7, GII/9, GII/13, GII/14, GII/15 were not available for Genogroup II. However, the fact that a large range of the genotypes were successfully amplified i.e. GI/1 to GI/6 and GII/2 to $\mathrm{GII} / 17$, coupled with the evidence based on multiple alignments of current sequence data available for NoV (data not shown) indicates that the RT-PCR assay 


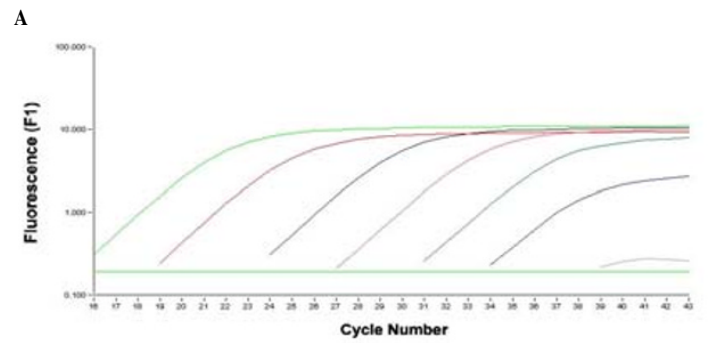

B

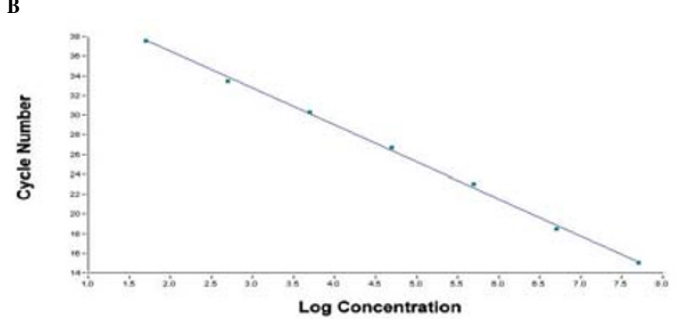

C

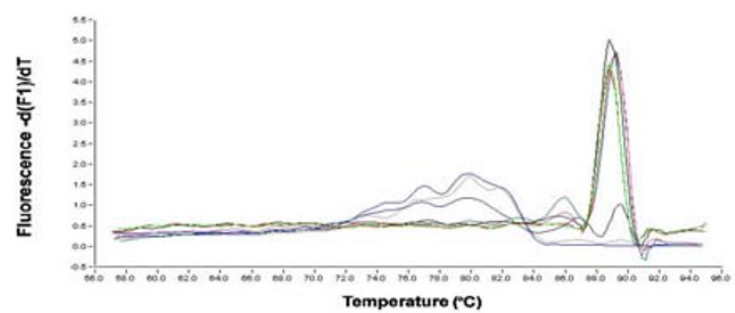

Figure 2

(A) Amplification of Gll standards showing fluorescence versus cycle number concentration of $5 \times 10^{7}-5 \times 10^{1}$ molecules are shown from left to right. (B) Standard curve of Gll assay $R_{2} I .00$ and a slope of -3.7 was obtained. (C) Melting curve of Gll standards showing melting point at $88^{\circ} \mathrm{C}$ in descending order $5 \times 10^{7}-5 \times 10^{1}$ molecules.

described here would be appropriate as a broad range detection method for NoV infection.

The real-time assay was used to detect and quantify the presence of $26 \mathrm{NoV}$ positive samples from 56 samples obtained from two Irish hospitals. The average titre of virus per gram of stool was found to be $1.02 \times 10^{9}$ molecules with the range of titre running from $2.67 \times 10^{6}$ per gram of stool to $7.53 \times 10^{9}$ molecules per gram of stool. These high levels are consistent with numbers reported in other studies of NoV levels in stools $[7,10]$.

The basis of this quantification was on assumption of $100 \%$ RT efficiency. This method allows a calculation of the minimum amount of NoV present based on cDNA values. Ideally quantification of an RNA virus involves the use of an RNA standard. However, RNA standards are not very stable, thus making standard curve construction difficult. It is more practical to use plasmids for the construction of an external standard curve. A recommendation to this problem would be the generation of an armoured RNA control for both GI and GII NoV similar to those available for Hepatitis C [11].

The genotyping of positive NoV obtained from outbreaks is usually performed by direct sequencing of the PCR products, a time consuming process. A first generation line-probe assay was created for genotyping NoV based on the highly conserved ORF1-ORF2 region. The primer pair described in this paper contains sufficient sequence variability between the primer binding sites to allow the design of specific probes for each genotype. The assay was validated using the stool panel of 14 different NoV genotypes. It was found that at an annealing temperature of $57^{\circ} \mathrm{C}$, both the GI and GII probes bound specifically to their genotypes present in the panel with the exception of GII/ 2 which also binds GII/6 (Fig. 3). Analysis of multiple sequences of GII/2 revealed that it was not possible to design a probe which would not bind GII/6. Therefore, it is not possible using this assay to differentiate GII/2 and GII/ 6 in an unknown sample.

No cross reactivity was observed between the probes GI/5, GI/7, GI/8 GII/1, GII/5, GII/7, GII/9, GII/13, GII/14, GII/ 15 with the genotypes present in the stool panel (Fig. 3). The lack of cross reactivity allows these probes to be left on the membrane and as they are designed to anneal to PCR products at the same temperature as the validated probes they should detect their corresponding genotypes in unknown samples.

Applying this assay to the 14 positives from the 2005 outbreak and the 12 positives from the 2006 outbreak (Fig. $4 \mathrm{~A}$ and $4 \mathrm{~B}$ ) detected by Real-time RT-PCR revealed that all 26 of the samples were genotype GII/4. This result was confirmed by sequencing of the RT-PCR products. The predominance of the GII/4 genotype is consistent with previous sequence analysis of Irish NoV isolates [12,13] and with that of other NoV circulating globally [14-17].

This paper describes both a rapid, sensitive and broadly reactive method for detecting and genotyping Human NoV. As the same sets of primers are used for both assays the combination of both methods greatly speeds up ascertaining when a NoV outbreak is occurring and which strain is responsible. A SYBR green mastermix containing a proof reading enzyme would again speed up the typing process as this would allow the RT-PCR products to be applied directly to the membrane by allowing biotin primers to be used in the initial detection of NoV. Assays like these have been developed for Human papillomavrius [18]. The genotyping assay would also be useful for 
Table 2: Stool panel acquired by this group 2003-2005.

\begin{tabular}{lll}
\hline Norovirus panel & Norovirus strain & Source \\
\hline Genogroup I & & \\
GI/I & Hu/NoV/West Chester/200I/USA & CDC, USA \\
GI/2 & Hu/NV/SHV/I993UK & UK \\
GI/3 & Hu/NV/Stav/I999/Nor & Irish isolate \\
GI/4 & Hu/Nv/Saitama T69GI/2002/JP & CDC, USA \\
GI/6 & Hu/Nv/Saitama T44GI/200I/JP & CDC, USA \\
Genogroup II & & \\
GII/2 & Hu/NoV/Melksham/200I/USA & CDC, USA \\
GII/3 & Hu/NoV/NannesLI69/2000/France & HPA, UK \\
GII/4 & Hu/NLV/GII/Carlow/2002/Irl & Irish isolate \\
GII/6 & Hu/NoV/SU4-JPN/2002/JP & CDC, USA \\
GII/8 & Hu/NoV/Saitama T67GII/2002/JP & HPA, UK \\
GII/I0 & Hu/NoV/Mc37/2004/JP & CDC, USA \\
GII/I2 & Hu/NoV/Honolulu/3I4/1994/US & CDC, USA \\
GII/I6 & Hu/NoV/Hiram/2000/USA & CDC, USA \\
GII/I7 & Hu/NoV/CS-EI/2002/USA & CDC, USA \\
\hline
\end{tabular}

CDC : Centres for Disease control

HPA: Health Protection agency

investigating outbreaks associated with water or oysters as it would allow typing of possible mixed infections which may occur due to the nature of both these contaminants. Future development of this assay would involve developing a disposable Line-probe assay based on these probes similar to those commercially available combined with automation to further improve the timeframe for genotyping a NoV infection.

\section{Conclusion}

A real time RT-PCR assay and a RLBH assay were developed and utilised to identify and genotype the causative agent of two gastroenteritis outbreaks in two Irish hospitals. The amount of Nov present in infected stool samples was estimated and the strain of NoV responsible for all positive cases was genotyped as the GII/4 variant.

\section{Methods}

\section{Clinical specimens}

A reference panel of various genotypes of $\mathrm{NoV}$ was acquired between January 2003 and December 2006 to determine the broad reactivity of the primers and probes. The panel was transported on dry ice and remained frozen at $-20^{\circ} \mathrm{C}$ until processing This panel was screened by RTPCR and the products were TA cloned (Invitrogen) (Table 2). Fifty six stool samples were collected from both Waterford Regional hospital and the Mercy Hospital Cork from January 2004 to March 2006 and stored at $4^{\circ} \mathrm{C}$ prior to processing.

\section{Primer and probe design}

A multiple alignment was performed using the MEGALIGN programme (DNASTAR). Thirty sequences of GI and 120 sequences of GII were aligned using this pro- gram. COG1F and COG2F primers described by [7] were chosen as forward primers for GI and GII assays respectively. Two reverse primers were designed based on these alignments and denoted G1NVR and G2NVR (Table 1).

Eight oligonucleotide probes were designed for the detection of GI NoV and 17 probes were designed for the detection of GII NoV. The probes were designed based on the criteria that they were at least 20 nucleotides in length and that they had a Tm of at least $60^{\circ} \mathrm{C}$. The probes were $5^{\prime}$ hexylamine labelled (Operon, Germany).

\section{Extraction of viral RNA}

Stools were diluted in a $10 \%(\mathrm{w} / \mathrm{v})$ Modified Eagles Medium (Gibco). The suspension was centrifuged at $10000 \mathrm{rpm}$ for $10 \mathrm{~min}$ and $200 \mu \mathrm{l}$ supernatant was applied to the High Pure Viral nucleic extraction kit (Roche). The extracted RNA was DNAse treated using RNAse free DNAse (Ambion).

\section{Reverse Transcription (RT)}

RT was performed using a Superscript II Reverse transcriptase kit (Invitrogen $^{\mathrm{TM}}$ ) to a final volume of $20 \mu \mathrm{l} .10 \mu \mathrm{l}$ of extracted RNA and $1 \mu \mathrm{l}$ of 75 pmole random hexamers (Roche) are added to a $0.5 \mathrm{ml}$ PCR reaction tube, mixed and heated to $95^{\circ} \mathrm{C}$ for $3 \mathrm{~min}$. A master-mix was prepared according to the manufacturer's instructions and incubated as directed.

\section{Detection of Norovirus}

NoV was detected by a Lightcycler assay (Roche Applied Science) designed in our laboratory based on the COG1FGINVR or COG2F-G2NVR primers (Table 1). Quantitative RT-PCR was performed using the LightCycler ${ }^{\circledR}$ Fast- 


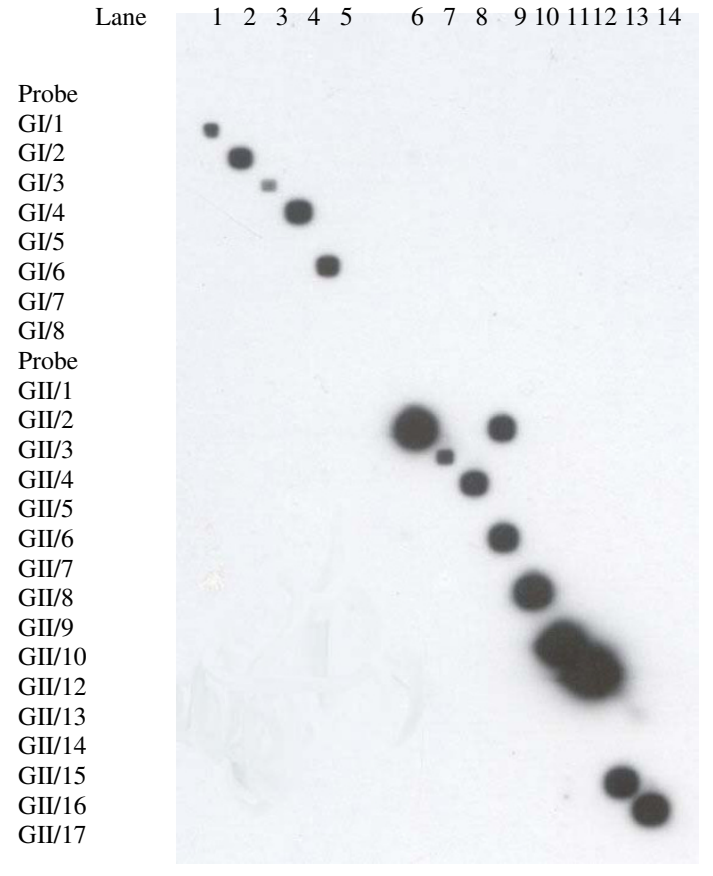

Figure 3

Validation of Reverse Line Blot hybridization using stool panel samples. Left of diagram indicates where the 25 probes are fixed across the membrane Top of the figure indicates where denatured PCR products of stool panel have been applied. Presence of spot indicates probe binding. Gaps between spots indicate unbound probes for which no reference samples are available. Lane I : GI/I, 2 : GI/2, $3: \mathrm{Gl} / 3,4$ : GI/4, $5: \mathrm{Gl} / 6,6$ : GII/2, $7: \mathrm{GII} / 3,9: \mathrm{GI} / 6,10$ : GII/8, II : GII/ I0, I2: GII/I2, I3: GII/I6, I4: GII/I7.

Start DNA Master SYBR Green I (Roche). A final reaction volume of $20 \mu \mathrm{l}$ containing $0.5 \mu \mathrm{l}$ of cDNA, $2 \mu \mathrm{l}$ of SYBR green Mastermix, $2.8 \mu \mathrm{l}$ of $25 \mathrm{mM} \mathrm{MgCl}_{2}$ (3.5 mM), $1 \mu \mathrm{l}$ of each primer $(0.6 \mu \mathrm{M})$ and $12.7 \mu \mathrm{l}$ of PCR grade water. The reaction was performed using GI primers with a denaturation step of $94^{\circ} \mathrm{C}$ for $8 \mathrm{~min}$ followed by 40 cycles at $94^{\circ} \mathrm{C}$ for $10 \mathrm{~s}, 45^{\circ} \mathrm{C}$ for $10 \mathrm{~s} 72^{\circ} \mathrm{C}$ for $15 \mathrm{~s}$ and a fluorescent read step of $85^{\circ} \mathrm{C}$ for $15 \mathrm{~s}$ to melt primer dimers.

The reaction was performed using GII primers with a denaturation step of $94^{\circ} \mathrm{C}$ for 8 min followed by 45 cycles of $94^{\circ} \mathrm{C}$ for $5 \mathrm{~s}, 52^{\circ} \mathrm{C}$ for $10 \mathrm{~s}, 72^{\circ} \mathrm{C}$ for $17 \mathrm{~s}$ and a fluorescent read step of $84^{\circ} \mathrm{C}$ for $10 \mathrm{~s}$ to melt primer dimers. For the creation of standard curves, $2 \mu \mathrm{l}$ containing dilutions of $10^{7}$ to $10^{1}$ molecules of GI/2 plasmid or $5 \times 10^{7}$ to $5 \times 10^{1}$ molecules of GII/4 plasmid DNA were added to the reaction tubes. All reactions were run with negative controls and subjected to melting curve analysis.

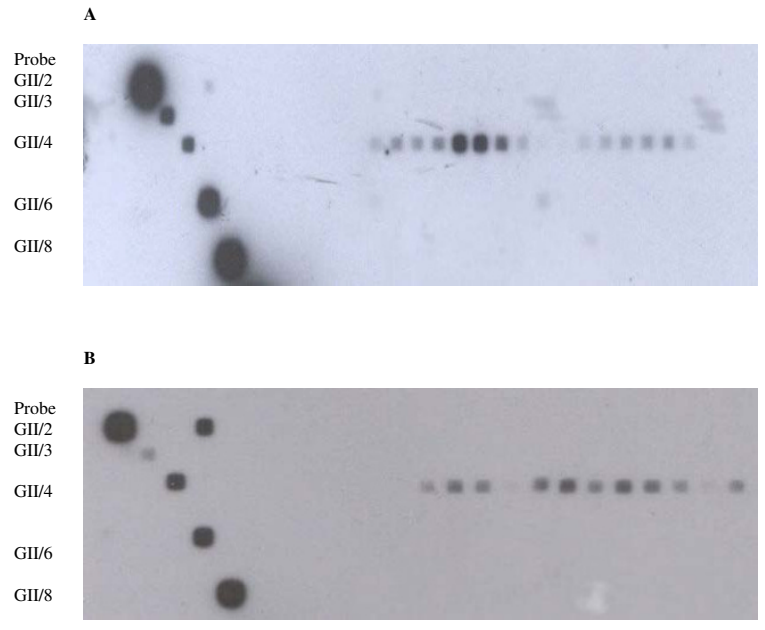

Figure 4

Genotyping of the (A) 14 positive samples from the 2005 outbreak and (B) 12 positive samples from the 2006 outbreak. Control samples containing known RT-PCR products from the reference panel are shown on the left binding to there respective probes. Clinical samples binding to probe GII/4 can be seen on the right of both $A$ and $B$.

\section{Biotinylated RT-PCR}

Biotinylated reverse primers G1NVR and G2NVR synthesized by MWG Biotech (Ebersberg, Germany) were used in the following RT-PCR assay at a final volume of $50 \mu \mathrm{l}$. The reaction contained $4 \mu \mathrm{l}$ of $\mathrm{cDNA}$ from the RT reaction, $5 \mu \mathrm{l}$ of $10 \times$ PCR Buffer, $1.5 \mathrm{mM} \mathrm{MgCl}_{2}, 1 \mu \mathrm{l}$ of $10 \mathrm{mM}$ each of dATP, dCTP, dGTP, and dTTP per reaction, $1 \mu \mathrm{M}$ each of primers and 2.5 units of Platinum Taq polymerase (Invitrogen) was performed on a MJ PTC-200 thermocycler (MJ research). The reaction was performed for GI with a denaturation step at $94^{\circ} \mathrm{C}$ for $3 \mathrm{~min}$, followed by 40 cycles at $94^{\circ} \mathrm{C}$ for $1 \mathrm{~min}, 45^{\circ} \mathrm{C}$ for $1 \mathrm{~min}, 68^{\circ} \mathrm{C}$ for $1 \mathrm{~min}$ and a final extension at $68^{\circ} \mathrm{C}$ for $7 \mathrm{~min}$. The PCR for GII was a denaturation at $94^{\circ} \mathrm{C}$ for $3 \mathrm{~min}$, followed by 40 cycles at $94^{\circ} \mathrm{C}$ for $30 \mathrm{~s}, 48^{\circ} \mathrm{C}$ for $30 \mathrm{~s}, 72^{\circ} \mathrm{C}$ for $1 \mathrm{~min}$ and a final extension at $72^{\circ} \mathrm{C}$ for $7 \mathrm{~min}$. The PCR products were separated on a $2 \%$ agarose gel and visualized by ethidium bromide staining. The PCR products for Genogroup I and Genogroup II were 387 bp and 378 bp in length, respectively.

\section{Reverse Line Blot Hybridization}

Twenty-five oligonucleotide probes each corresponding to a GI or GII genotype (Table 2) which were synthesized with a 5 ' hexylamino group (Operon Biotechnologies Ltd, 
Cologne, Germany). The oligonucleotides were covalently bound to a negatively charged nylon membrane (Biodyne C; Pall Biosupport, Portsmouth, Cambridge, United Kingdom) by this 5 ' hexylamino group. Briefly, the carboxyl groups on the membrane were activated by incubation for $10 \mathrm{~min}$ in $16 \%$ (w/v) 1-ethyl-3-(3-dimethylaminopropyl) carbodimide (EDAC) (Sigma). The membrane was washed with tap water and placed in a miniblotter system (MN45; Immunetics, Cambridge, Massachusetts). The slots were filled in parallel with 150 $\mu \mathrm{l}$ of each of the 5'-hexylamine-labeled oligonucleotides at a final concentration of $1 \mu \mathrm{M}$ diluted in freshly prepared $0.5 \mathrm{M} \mathrm{NaHCO} 3[\mathrm{pH} 8.4]$ and after $1 \mathrm{~min}$ of incubation at room temperature, the excess solution was aspirated and the membrane was removed from the miniblotter. The remaining active esters on the membrane were hydrolyzed by incubation in $0.1 \mathrm{M} \mathrm{NaOH}$ for $8 \mathrm{~min}$ at room temperature and rinsed in water. The membrane was washed twice for $5 \mathrm{~min}$ at $60^{\circ} \mathrm{C}$ in $2 \times \operatorname{SSPE}$ (Sigma) with $0.1 \%$ sodium dodecylsulfate (SDS) (BDH, Poole, United Kingdom). The membrane was used immediately or washed for $15 \mathrm{~min}$ in $20 \mathrm{mM}$ EDTA and stored sealed in plastic at $4^{\circ} \mathrm{C}$.

Prior to use in hybridization, the membrane was washed for $5 \mathrm{~min}$ in $2 \times$ SSPE- $0.1 \%$ SDS, placed in the miniblotter. The membrane was rotated so that the probes were perpendicular to the previous position. $15 \mu \mathrm{l}$ of each PCR product in $135 \mu \mathrm{l}$ of $2 \times$ SSPE- $0.1 \%$ SDS was denatured by heating to $99^{\circ} \mathrm{C}$ for $10 \mathrm{~min}$ and chilled on ice. The slots were then filled with $150 \mu \mathrm{l}$ of PCR product and incubated for $60 \mathrm{~min}$ at $57^{\circ} \mathrm{C}$ in a hybridization oven. After hybridization, unbound PCR product was removed by washing twice with prewarmed $2 \times$ SSPE- $0.5 \%$ SDS at $60^{\circ} \mathrm{C}$ for 10 $\min$. The membrane was then incubated at $42{ }^{\circ} \mathrm{C}$ in $10 \mathrm{ml}$ of 1:2000 dilution of streptavidin-peroxidase conjugate (Roche) in prewarmed $2 \times$ SSPE buffer for $1 \mathrm{hr}$. Unbound streptavidin-conjugate was removed by washing twice with $2 \times$ SSPE- $0.5 \%$ SDS at $42^{\circ} \mathrm{C}$ for $10 \mathrm{~min}$. lastly the membrane was washed twice with $2 \times$ SSPE at room temperature for $5 \mathrm{~min}$ to remove SDS.

The bound PCR products were detected by a chemiluminescence assay using ECL detection liquid (Roche) and visualized by exposure of the blot for $10 \mathrm{~min}$ to $3 \mathrm{hrs}$ to an X-ray film (Hyperfilm; Amersham). For repeated use, the membranes were stripped twice in $1 \%$ SDS at $80^{\circ} \mathrm{C}$ for $30 \mathrm{~min}$ and incubated for $15 \mathrm{~min}$ at room temperature in $20 \mathrm{mM}$ EDTA solution, the membranes were sealed and stored at $4{ }^{\circ} \mathrm{C}$ until further use.

\section{Abbreviations}

Norovirus (NoV); Reverse transcription PCR (RT-PCR); Genogroup I (GI); Genogroup II (GII); Reverse Line Blot Hybridisation (RLBH).

\section{Competing interests}

The author(s) declare that they have no competing interests.

\section{Authors' contributions}

JFM is the corresponding author and main contributing author of this manuscript. KK contributed to primer design, the construction of the plasmids used for standard curve generation and the final review of the manuscript. Supervision and final review of the manuscript was provided by JGM. All authors have read and approved the final manuscript.

\section{Acknowledgements}

We are most grateful to Dr. Stephen Monroe, Dr. Suzanne Beard, Dr. Kim Green, Dr. lan Clark and Dr Chris Gallimore and their various institutions for providing us with a Norovirus reference panel. Funding provided by the Food Institutional Research and Development Measure 3 (ii) Food Sub-Programme (Dept. of Agriculture and Food, Republic of Ireland). Thank you to Mr. Noel Shanaghy and Mrs. Breda Doody of Waterford Regional Hospital, Mr. Eddie Beggan of Limerick Regional Hospital and Dr. Jim Clair of the Mercy Hospital Cork for providing us with faecal samples.

\section{References}

I. Kapikian AZ: The discovery of the 27-nm Norwalk virus: an historic perspective. J Infect Dis 2000, I8I Suppl 2:S295-302.

2. Saito $\mathrm{H}$ : [Epidemiology on Norwalk virus-related gastroenteritis outbreaks among elderly persons living in nursing homes]. Nippon Rinsho 2002, 60(6): I | 148-I I 53.

3. Gallimore $\mathrm{Cl}$, Richards AF, Gray JJ: Molecular diversity of noroviruses associated with outbreaks on cruise ships: comparison with strains circulating within the UK. Commun Dis Public Health 2003, 6(4):285-293.

4. Blanton LH, Adams SM, Beard RS, Wei G, Bulens SN, Widdowson MA, Glass RI, Monroe SS: Molecular and epidemiologic trends of caliciviruses associated with outbreaks of acute gastroenteritis in the United States, 2000-2004. J Infect Dis 2006, 193(3):4|3-42|.

5. Lang L: Acute gastroenteritis outbreaks on cruise ships linked to Norwalk-like viruses. Gastroenterology 2003, I 24(2):284-285.

6. Zheng DP, Ando T, Fankhauser RL, Beard RS, Glass RI, Monroe SS: Norovirus classification and proposed strain nomenclature. Virology 2006, 346(2):3| 2-323.

7. Kageyama T, Kojima S, Shinohara M, Uchida K, Fukushi S, Hoshino FB, Takeda N, Katayama K: Broadly reactive and highly sensitive assay for Norwalk-like viruses based on real-time quantitative reverse transcription-PCR. J Clin Microbiol 2003, 4I(4): I548-I557.

8. Kojima S, Kageyama T, Fukushi S, Hoshino FB, Shinohara M, Uchida K, Natori K, Takeda N, Katayama K: Genogroup-specific PCR primers for detection of Norwalk-like viruses. J Virol Methods 2002, I 00(I-2): I07-II4.

9. O'Neill HJ, McCaughey C, Wyatt DE, Mitchell F, Coyle PV: Gastroenteritis outbreaks associated with Norwalk-like viruses and their investigation by nested RT-PCR. BMC Microbiol 200I, I: 14 .

10. Pang X, Lee B, Chui L, Preiksaitis JK, Monroe SS: Evaluation and validation of real-time reverse transcription-pcr assay using the LightCycler system for detection and quantitation of norovirus. I Clin Microbiol 2004, 42( I 0):4679-4685.

II. WalkerPeach CR, Winkler M, DuBois DB, Pasloske BL: Ribonuclease-resistant RNA controls (Armored RNA) for reverse transcription-PCR, branched DNA, and genotyping assays for hepatitis C virus. Clin Chem 1999, 45(1 2):2079-2085.

12. Waters A, Coughlan S, Dunford L, Hall WW: Molecular epidemiology of norovirus strains circulating in Ireland from 2003 to 2004. Epidemiol Infect 2006, 134(5):917-925

13. Foley B, O'Mahony J, Hill C, Morgan JG: Molecular detection and sequencing of "Norwalk-like viruses" in outbreaks and spo- 
radic cases of gastroenteritis in Ireland. I Med Virol 200I, 65(2):388-394.

14. Lynch M, Painter J, Woodruff R, Braden C: Surveillance for foodborne-disease outbreaks--United States, 1998-2002. MMWR Surveill Summ 2006, 55(10): I-42.

15. Vainio K, Myrmel M: Molecular epidemiology of norovirus outbreaks in Norway during 2000 to 2005 and comparison of four norovirus real-time reverse transcriptase PCR assays. J Clin Microbiol 2006, 44(1 0):3695-3702.

16. Koopmans M, Harris J, Verhoef L, Depoortere E, Takkinen J, Coulombier D: European investigation into recent norovirus outbreaks on cruise ships: update. Euro Surveill 2006, I I(7):E060706 5 .

17. Kearney K, Menton J, Morgan JG: Carlow Virus, a 2002 GII.4 variant Norovirus strain from Ireland. Virol J 2007, 4(I):6I.

18. Payan C, Ducancelle A, Aboubaker MH, Caer J, Tapia M, Chauvin A, Peyronnet D, Le Hen E, Arab Z, Legrand MC, Tran A, Postec E, Tourmen F, Avenel M, Malbois C, De Brux MA, Descamps P, Lunel F: Human papillomavirus quantification in urine and cervical samples by using the Mx4000 and LightCycler general realtime PCR systems. J Clin Microbiol 2007, 45(3):897-90I.

Publish with Bio Med Central and every scientist can read your work free of charge

"BioMed Central will be the most significant development for disseminating the results of biomedical research in our lifetime. "

Sir Paul Nurse, Cancer Research UK

Your research papers will be:

- available free of charge to the entire biomedical community

- peer reviewed and published immediately upon acceptance

- cited in PubMed and archived on PubMed Central

- yours - you keep the copyright

Submit your manuscript here:

http://www.biomedcentral.com/info/publishing_adv.asp 